\title{
Towards Developing a Mechanistic Understanding of Coral Reef Resilience to Thermal Stress Across Multiple Scales
}

\author{
Ronan C. Roche ${ }^{1} \cdot$ Gareth J. Williams ${ }^{1}$. John R. Turner ${ }^{1}$
}

Published online: 17 January 2018

(C) The Author(s) 2018. This article is an open access publication

\begin{abstract}
Coral reefs are a globally threatened ecosystem due to a range of anthropogenic impacts. Increasing sea surface temperatures associated with global warming are a particular threat, as corals grow close to their upper thermal limit. When this limit is exceeded for a sufficient length of time during thermal stress events, corals lose their algal symbionts, resulting in coral bleaching and possible mortality. Coral reefs have experienced the most severe and extended global bleaching event to date from 2014 to 2017. The most recent global climate models predict that similar global bleaching events are likely to become an annual occurrence by the middle of the present century. Current understanding of coral reef recovery following disturbance events is based around decadal to sub-decadal impacts, making the adaptive capacity of corals as bleaching events approach an annual frequency unknown. However, there is considerable spatial heterogeneity in bleaching impacts across a range of scales, from global reef provinces to local reef areas and between coral species. Understanding of the mechanisms responsible for this observed coral resilience to thermal stress is increasing in a variety of disciplines, with particular recent advances at the subcellular level, facilitated partly by technological developments. This understanding suggests that some resilience factors have the potential to operate within the predicted annual frequency of thermal stress events, whilst others act over longer time-scales. The ability of coral reef management actions to successfully support coral resilience is a significant challenge and requires increased empirical evidence to support and refine actions. However, in addition to essential global actions to reduce carbon dioxide emissions, protective actions can be strengthened by a focus on identifying reef locations that have the potential to exhibit resilience to thermal stress events, either via resisting them or recovering quickly following impact. Here, we present a spatially explicit overview of the potential resilience factors and mechanisms that can be considered in such an approach.
\end{abstract}

Keywords Coral reefs $\cdot$ Spatial resilience $\cdot$ Climate change $\cdot$ Thermal stress $\cdot$ Coral bleaching $\cdot$ Microbiome

\section{Introduction}

Ecological assessments of coral reefs over the last several decades have been dominated by reports of degradation, sustained declines in live coral cover and shifts in coral assemblage composition [1-3]. These declines in coral reef condition have been principally attributed to anthropogenic impacts and disturbances, in particular those arising from global

This article is part of the Topical Collection on Corals and Climate Change

Ronan C. Roche

r.roche@bangor.ac.uk

1 School of Ocean Sciences, Bangor University, Menai Bridge, Anglesey LL59 5AB, UK climatic change [4]. The increased frequency and intensity of climate-related disturbances has been suggested as a defining feature of an emerging Anthropocene era, in which global coral reef loss and alteration intensifies [5]. The extent to which these predicted changes and reduced functioning will occur is dependent on the resilience that coral reefs, as inherently complex bio-geological systems, display in response to future climate change impacts. Coral reefs possess the key properties of reorganisation, recovery and adaptation following disturbances and have demonstrated their ability to respond to natural disturbances over geological time-scales.

The continuing accumulation of atmospheric carbon dioxide is associated with several alterations in global environmental conditions which are expected to challenge global coral reef resilience: increases in sea surface temperatures (SSTs), changes in ocean chemistry (ocean acidification), and to a lesser extent, alterations in tropical storm frequency and sea- 
level rise [6]. There are considerable differences in the timescales over which these processes operate, but it is increasingly recognised that warmer SSTs represent the most immediate threat to continued coral reef functioning [5, 7]. Corals are highly sensitive to changes in SST as their growth is facilitated by an algal symbiosis that usually provides the majority of coral energy requirements [8]. This symbiosis breaks down under conditions of thermal stress, when the production of reactive oxygen species stimulates the expulsion or removal of the algal endosymbiont $[8,9]$. The coral skeleton can then be observed through transparent tissue, and the coral appears pale or 'bleached'. Recovery from bleaching does occur if the algal symbionts are reacquired before the coral's energy reserves are depleted; however, if prolonged, mortality results [10]. In spite of this, there are aspects to the bleaching process which indicate that it has some protective or adaptive functions within the symbiosis, by reducing host heat stress, and possibly facilitating host-algal combinations with higher temperature tolerances [11-13].

While coral bleaching at local to regional scales has been reported since the early 1980s [14, 15], recent events appear unprecedented in their scale and intensity. The 1998 event associated with El Niño Southern Oscillation (ENSO) thermal anomalies was the first widely reported 'pan-tropical' event with impact across the Indian Ocean, Pacific Ocean and the Caribbean $[6,16]$. Since this event, there have been a further series of regional to global scale events, with notably widespread bleaching occurring in the Eastern Caribbean in 2005, and in Southeast Asia and western Australia in 2010 [17]. The most recent bleaching event which began in 2014 and continued in 2015, 2016 and 2017 [18], was again driven by strong ENSO patterns and was pan-tropical, with extensive coral bleaching in the northern Australian Great Barrier Reef (GBR), the Indian Ocean and the North and South Pacific $[19,20]$.

There have been several areas of research focus in response to these events: estimation of future bleaching frequency from modelled global warming trends [18, 21-23], the identification of characteristics that may confer resilience to present and future bleaching events [1-3, 24], and a focus on understanding bleaching at a sub-cellular level $[4,25]$. All research areas have expanded and developed in sophistication during recent decades, but two principle areas of uncertainty remain: the trajectory of global $\mathrm{CO}_{2}$ emissions and the role of ecological and social adaptive capacity in supporting reef resilience. Early studies utilised atmosphere-ocean general circulation models (GCMs) combined with regionally observed bleaching thresholds to arrive at predictions of bleaching frequency $[5,23,26]$. The return time between bleaching events appears critical in governing coral reef recovery and adaptive ability $[5,6,22,27]$. It has been broadly suggested that coral reefs may tolerate two bleaching events per decade $[5,7,28]$, whilst annual severe bleaching (ASB) has been used as an 'end-point scenario' which would overwhelm the essential ecological processes underpinning recovery $[8,22]$, although many ecological processes would likely become compromised well before this frequency is reached. Incorporating future carbon emission trajectories captured within the most recent representative concentration pathways (RCPs) illustrates the impact of varying atmospheric $\mathrm{CO}_{2}$ concentrations on the time-point at which all coral reefs experience ASB: from 2056 for the RCP 8.5 'business-as-usual' scenario to extending this point beyond 2100 for RCP 2.6 in which strong emission reductions are realised [8, 9, 22, 29].

Several studies have sought to evaluate the increase in coral thermal tolerance which would be required to reduce coral mortality following bleaching events, or bleaching from an annual or sub-annual event to a 5-10-year return frequency $[10,21,30,31]$. Combining GCM projections and degree heating weeks (DHW) as a predictor of bleaching for global coral reefs has found that an increase of $0.2-1.0^{\circ} \mathrm{C}$ of thermal tolerance per decade is required for this reduction in frequency to ecologically sustainable levels to occur [11-13, 21]. Where coral adaptation rates have been simulated (as functions of historical exposure to maximum SSTs) and incorporated into GCM models coupled with bleaching sensitivity, substantial changes in future bleaching frequency are observed which confirm the importance of adaptive or resilience mechanisms for coral reef persistence $[14,15,28]$. Simulation studies have also begun to explore the relationship between coral traits, life history strategies and demographic properties on the ability of corals to persist and survive under projected future environmental conditions [6, 16, 32, 33].

Whilst the spatial resolution of GCM models has been increasing [17, 21, 34], a lack of congruence remains between model scales of $\sim 100 \mathrm{~km}$ and the scales of variability in coral response to thermal stress that are observed [18, 35]. The scales at which processes contributing to coral reef resilience have been examined range from global biogeographic provinces to the sub-cellular, and many of the mechanisms that have been recently identified as contributing to coral thermal resilience operate at the reef site, individual coral colony and microbiome scales. Identifying the most important resilience factors over multiple scales is a significant challenge, and the body of empirical evidence that resilience-based management (RBM) produces effective outcomes on coral reefs remains scarce at present. This is partially due to the fact that whilst some management agencies have implemented measures which individually build resilience (e.g. reducing land-based pollution or protecting herbivory), few, if any, have moved to an explicit strategic focus on RBM. Nonetheless, there is a widespread desire to translate resilience concepts into practical coral reef management measures, and theoretical studies have shown how resilience principles could be operationalised to maximise performance under future climate change scenarios [19, 20, 36-38]. Continuing to facilitate a transition from 
the theoretical to the practical requires determining which aspects of resilience can best be supported by management, and will require refining existing methods, and considering new approaches to identifying reef areas as conservation targets. Here, we review recent developments in the understanding of coral reef resilience to thermal stress across scales (Fig. 1), and further consider the implications of future global climate change scenarios on the factors to date assumed to convey resilience potential to coral reef ecosystems.

\section{Coral Reef Resilience Concepts}

Resilience concepts are embedded within broader ecological theories of regime shifts, thresholds and the existence of alternative stable states within ecosystems [39]. Coral reef resilience stems from the initial premise that there are some reef areas, which, by virtue of a range of factors, will be more likely to resist substantial change or will rebound following disturbance. Part of the development of the concept of coral reef resilience can be linked to concerns which arose in the aftermath of the 1998 ENSO event on coral reefs globally [40]. There has been a proliferation in definitions of resilience, as the popularity of the concept has steadily increased [41]. For the present study, we will adopt a definition of coral reef resilience which includes two main elements: the capacity to resist climate change disturbances and adapt to changing conditions and to recover, conserving function and structure following disturbances [37, 42, 43].
It is challenging to attempt any quantification of coral reef resilience, as aspects of resilience may only be observed following disturbances, but the value of the concept has been widely recognised, and suites of 'resilience indicators' have been proposed. Obura and Grimsditch [44] identified 61 potential coral reef resilience indicators - but obtaining values for this variety of indicators is rarely feasible, and selection criteria between indicators are often unclear [37]. Since these early frameworks, sufficiently detailed studies have implied that broad-scale ecosystem recovery is associated with, or can be predicted by relatively few resilience factors operating at a given scale $[37,45]$.

An emerging resilience-based management (RBM) approach advocates combining a sub-set of resilience indicators to examine resilience potential across spatial scales of interest $[46,47]$. The selection criteria and numbers of indicators to incorporate into assessments remain relatively uncertain, and efforts are often influenced by local data availability rather than indicator robustness [37, 47]. Ideally, before-aftercontrol-impact studies would be carried out to test the validity of resilience indicators [37]. To date, relatively little research in this area has been carried out, and additional uncertainties surround the degree to which a resilience indicator developed from one reef location is applicable to sites in other regions. Nevertheless, methods for the practical application of resilience theory to coral reef ecosystems have been sought after for at least a decade $[39,43]$, making recent studies that have actively informed and influenced management a welcome development. Understanding of the mechanisms contributing to
Fig. 1 Schematic illustration of the spatial scales of resilience examined within this study, together with a summary of some of the main resilience factors identified in the literature at each scale

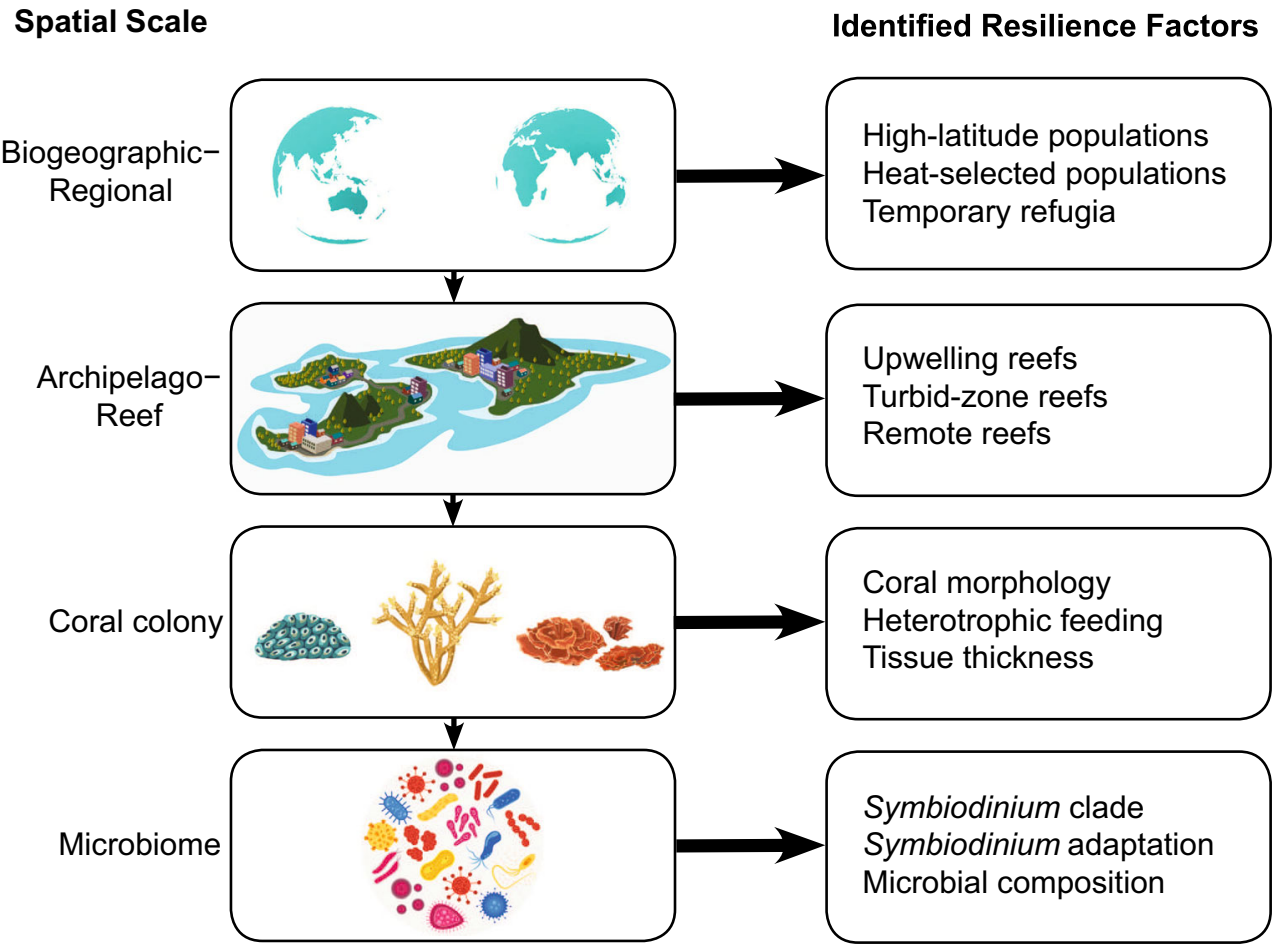


coral reef resilience across all scales is growing, and the most recent 2014-2017 global bleaching event offers an opportunity to empirically test variables thus far identified as holding the key to high resilience potential on coral reefs.

\section{Regional Coral Resilience Variation}

Efforts to identify potential mechanisms of thermal resilience have been informed by atypical regional coral populations that presently exist in a thermal regime similar to that predicted under future climate change. The coral populations growing within the Gulf of Oman and the Persian Gulf present an apparent paradox in typical tropical coral thermal thresholds, in that they regularly experience seasonal maxima of 32$36{ }^{\circ} \mathrm{C}$ without exhibiting a bleaching response. These populations have been exposed to higher temperatures for $\sim 6 \mathrm{ka}$ years [48], and therefore demonstrate the adaptive potential of corals over evolutionarily relevant time-scales. Although adapted to an extreme local temperature regime, when high seasonal maxima persist, these coral populations also experience bleaching and subsequent mortality, and have bleached repeatedly during ENSO events in 1998, 2002 and 2010, in which $>34{ }^{\circ} \mathrm{C}$ maintained for $\sim 8$ weeks resulted in $60-80 \%$ bleaching prevalence [49].

This reinforces the understanding that thresholds for coral bleaching are $1-3{ }^{\circ} \mathrm{C}$ above regional maximum monthly mean and that coral populations are highly adapted to prevailing local to regional thermal conditions $[50,51]$. Therefore, the potential thermal resilience of Persian Gulf corals would only be realised within a different thermal regime. The active translocation of corals from this region into wider Indo-Pacific or the 'assisted migration' of corals from the Persian Gulf into the Indian Ocean have both been suggested as methods to sustain these broader coral populations within a warming climate, but the considerable challenges and risks in any such approach are clearly evident and acknowledged [49, 52].

The Gulf of Aqaba is an additional location of potentially thermal resilient corals [53]. The corals within this region are descended from heat-selected populations that developed within the southern Red Sea, over several millennia, and subsequently dispersed northward to the cooler northern portions of the Red Sea and the Gulf of Aqaba. As a result of this evolutionary history, these corals are now living well below their thermal threshold, with recent experimental manipulation confirming this hypothesis [54]. This is further supported by the absence of observed beaching events in the Gulf of Aqaba during 2010 and 2012, whilst widespread bleaching was recorded within neighbouring areas of the Red Sea and the Gulf of Aden [53].

The persistence or potential expansion of high latitude reefs currently on the margin of the geographical distribution of corals has been postulated as a potential regional refuge under a warming climate $[40,55]$. This concept draws on evidence of spatial shifts in corals within the Pleistocene and Holocene eras [56], with Acropora-dominated reefs along the east coast of Florida, and reefs extending $\sim 500 \mathrm{~km}$ further south along the western Australian coastline [4]. There is evidence that the 'tropicalisation' of a range of temperate ecosystems is currently taking place $[57,58]$. For coral reefs, bio-physical constraints on this concept have been noted, including differences in the relatively small projected future sea-level rise in comparison to the Pleistocene sea-level rise, the decrease in light levels at higher latitudes, and the availability of suitable habitat for recruitment and colonisation to occur $[4,59]$. Studies examining the genetic variation within corals present on these reefs have found reduced levels of genetic diversity [60], and evidence that adaptation within areas of the genome associated with thermal tolerance has occurred [61]. This suggests that a lack of gene flow to existing high-latitude reefs could hamper coral range expansion and that the corals present in these locations may have a reduced capacity to respond to future increases in SST.

An additional component of regional-scale variation in coral reef resilience has become apparent from predictions of the thermal anomalies associated with bleaching across global scales. GCMs indicate spatial heterogeneity in ocean warming trends, such that some regions experience a slower increase in annual SST maxima and will therefore reach seasonal bleaching thresholds further into the future [6, 62]. Through examining future bleaching frequencies, van Hooidonk et al. $[29,63]$ identified reef regions where annual bleaching conditions are expected to occur 5-20 years later than the global mean year of 2043. These regions include the southern GBR, areas of Sulawesi, Indonesia, Papua New Guinea, and Cuba, and are suggested to represent 'temporary refugia' from thermal stress. Differences in the relative timing of bleaching events are an important aspect to identifying potential target areas for conservation efforts, but reef exposure or 'experience' of previous thermal stress events also appears to be a component of resilience. The bleaching response following thermal stress exposure may vary between global ocean regions: reports from the GBR of a lack of an adaptive response over repeated events [5] contrast with those from Kenya which indicate a reduction in the severity of response from 1998 to 2016 [12]. Aspects of thermal regime 'quality' also have an effect - areas which experience greater variability in SSTs have widely been found to be less susceptible to bleaching [64-66], whilst temperature trajectories which exceed regional seasonal maxima but remain below bleaching thresholds can also act to increase thermal tolerance [67].

\section{Coral Reef Site Resilience}

There are a variety of physical or environmental factors operating predominately at reef to archipelago scales that have been associated with resistance to bleaching events, although 
the exact mechanism (i.e. cooling, increased food supply etc.) responsible for this resistance is not always identified. Many of these manifest in the spatial variation in coral bleaching observed over these scales during bleaching events $[68,69]$. A reduction or complete absence of bleaching was observed at reef locations associated with upwelling zones during the 1998 global bleaching event around central Indonesia, Western Zanzibar [16, 24], and Vietnam [70]. Areas of strong currents can function similarly-with both field-based and lab-based experimental evidence that high currents can prevent bleaching and minimise associated mortality [71], although there is also evidence that high currents can in some instances prevent acclimatisation and increase coral sensitivity to temperature anomalies [72].

The timing of oceanographic processes generating upwelling and currents coinciding with thermal stress events is critical [73], and identification of reef areas expected to display resilience due to upwelling processes is complicated by the disruption of typical patterns which occurs during ENSO events. Indeed, patterns between successive ENSO events are not necessarily consistent, and Wolanski et al. [74] point to an alteration of the usual pattern over the northern GBR which resulted in particularly high thermal stress during the 2016 ENSO event. The capacity of corals to acclimatise to local thermal conditions is also evident within upwelling zones - corals from these areas are more sensitive to temperature increases than conspecifics from non-upwelling areas [75], potentially limiting their ability to act as thermal refugia.

There is a growing body of research which indicates that nearshore turbid-zone reefs, often considered as marginal for coral growth, demonstrate a capacity to withstand levels of thermal stress that commonly result in a coral bleaching response $[16,76]$. The resilience of these reef sites has been observed in nearshore areas of East Africa in 1998 [77], Florida during the 2010 bleaching event [78], and more recently in inner-shelf turbid zones of the GBR during the 20152017 event [79]. Although the mechanisms underlying this observed resilience are not fully understood, it is likely that, rather than any direct SST influence, a combination of reduced irradiance and UV due to high suspended sediment concentrations and higher levels of heterotrophic feeding are involved [79-81]. However, the role of turbidity is not universally protective; Hongo et al. [82] contrast the higher recovery rates at non-turbid reef sites with the reduced recovery observed at adjacent 'anthropogenically turbid' reefs around Okinawa. These observations are likely related to the short time-scales which these reefs have had to acclimatise and adapt, relative to reefs which have established and developed under high turbidity conditions.

Where the role of turbidity has been incorporated into modelled predictions of coral distributions under future climate change scenarios, findings indicate that turbidity could mitigate the effects of higher temperatures for $9 \%$ of global shallow $(<30 \mathrm{~m})$ reef habitat [83]. Areas identified as potential climate change refugia were the turbid nearshore habitats of Hawaii, reefs in the northern Philippines, southern Japanese islands and areas in the northern Gulfs of the Indian Ocean. Although this model incorporated 12 coral species categorised as both thermally tolerant and sensitive, within these, it predicted that the resistance to thermal stress provided by high turbidity areas would act unequally across coral species, favouring Porites and Montipora [83]. Whilst typically considered as degraded or less 'aesthetically appealing' than clear water reef locations, naturally turbid reef sites could nonetheless constitute an important source of resilience to thermal stress events.

A factor which might be more intuitively associated with reef resilience potential is remoteness; reefs where ecosystem processes are operating in as natural a state as possible and resilience is therefore maximised, primarily by virtue of their isolation from direct anthropogenic influences. However, it is arguable whether any reef sites globally are truly without human impact [84], and it is recognised that even minimal levels of human impact affect coral reef communities [85, 86]. More realistically, there are degrees of remoteness and isolation which some reefs experience by virtue of their geography or political history. Remoteness may also hamper recovery following bleaching events if rates of larval transport and gene flow are reduced [4]. Where it has been possible to examine recovery patterns in remote reefs, observed patterns suggest that the absence of chronic anthropogenic pressures offset their limited connectivity. Following mass coral bleaching during the 1998 ENSO event, the remote Scott reef system off Western Australia lost $80-90 \%$ of live coral, but recruitment levels recovered within 8 years, driving reef-wide recovery within 12 years [87]. Similarly, following the same global bleaching event, most reefs of the remote Chagos Archipelago in the Indian Ocean exhibited strong recovery patterns within 8 years [88]. Remote reefs have not escaped global bleaching events and associated mortality, but are where some of the most rapid recovery trajectories have been observed.

The degree to which a reef is connected to other individual reefs, or habitat patches (reef connectivity) via larval exchange is a key element of resilience, driving recovery following disturbance. An assessment of spatial patterns of connectivity can identify reefs which can serve as high-quality sources, and 'stepping-stones' or those which are isolated subpopulations [89]. Recent modelling efforts for the Pacific Ocean indicate that long-distance connectivity between reefs is not as pervasive or consistent as previously assumed [90]. However, ultimately for long-term reef persistence, what matters is 'demographic connectivity', encompassing coral reproduction frequency and success, recruitment and postsettlement mortality processes. Utilising these processes to derive novel reef resilience metrics has been suggested during the last decade [91-93], and studies are increasingly 
incorporating these aspects into resilience assessments [94-96]. Continuing to focus on assessing reproduction and recruitment as fundamental ecological processes will facilitate managing for reef resilience more than traditional assessments of ecosystem state and condition [97].

\section{Individual Coral Colony Resilience}

Variation in resistance to thermal stress between individual coral colonies is frequently observed as differences in the severity, or the timing of bleaching between coral genera present on a reef(Fig. 2a). Surveys conducted during bleaching events often present a hierarchy of susceptibility from 'thermally sensitive' genera to 'thermally resistant' genera [72, 98, 99]. Generally, Acropora, Pocillopora, Stylophora and Montipora are among the 'thermally susceptible' genera, with Porites, Pavona and Turbinaria among the least susceptible [66, 98, $100,101]$. Recently, this taxonomic variation in bleaching susceptibility has been summarised in a meta-analysis of 68 studies reporting within the Indo-Pacific, and the results confirm differences of $>80 \%$ in the mean percentage of colonies bleaching between genera and find that the extremes of high and low susceptibility are represented by finely branched Seriatopora and the free-living mushroom coral Heliofungia, respectively [102].

Massive and encrusting growth morphologies consistently emerge as more resistant to bleaching than branching and
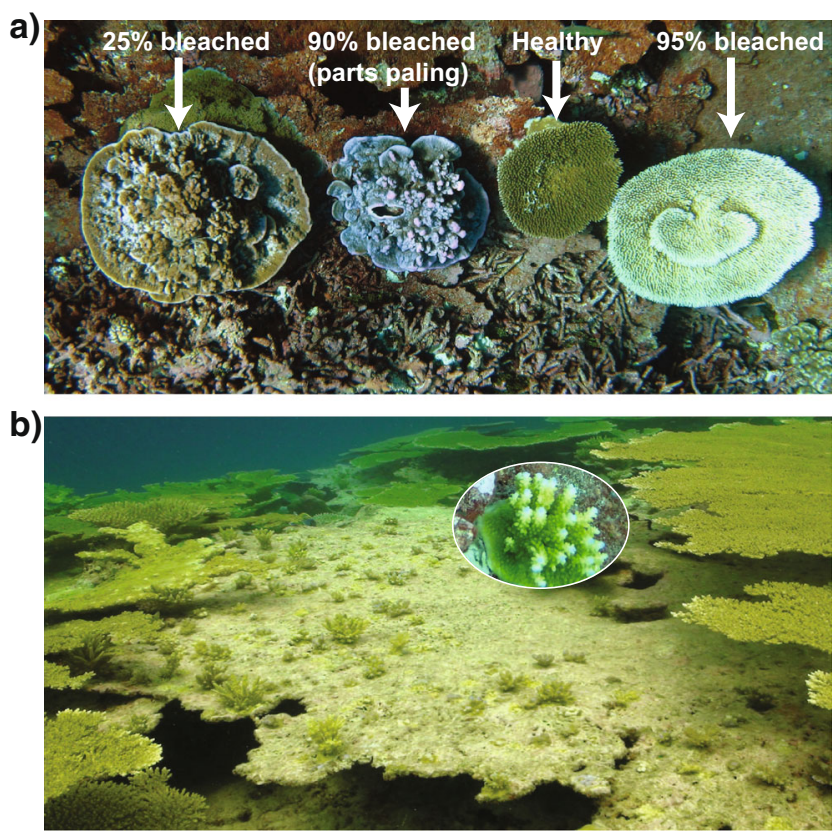

Fig. 2 Factors contributing to reef resilience at two remote reef sites. a Variability in bleaching severity in adjacent Montipora and Acropora conspecific colonies during a 2009 bleaching event at Palmyra Atoll. From [66]. b Coral recruitment onto dead tabular Acropora with Peros Banhos Atoll, Chagos Archipelago. High levels of Acropora recruitment can drive rapid recovery-Acropora recruit shown within inset digitate forms $[11,99,103,104]$. Potential mechanisms explaining this trend include the following: (1) more efficient removal of cellular toxins which accumulate during bleaching events due to higher mass transfer efficiencies in massive corals; (2) massive coral colonies generally possess greater tissue thickness, which may facilitate bleaching resilience via photoprotection $[105,106]$; additionally, it has been hypothesised that the thicker layer allows for a broader gradient in conditions within this microhabitat, reducing internal fluctuations and facilitating acclimatisation [25].

Rates of coral mortality following bleaching have largely followed the same pattern, with lowest mortalities among massive and encrusting growth forms [107, 108]. Initial studies have supported the consistency of this resilience hierarchy across broad geographic scales [109]. The implications of these patterns are that under the increasingly frequent bleaching events predicted within GCM, coral community assemblages will shift towards dominance by resilient growth forms, driven by selective mortality, rather than any 'die-off' affecting all corals at the same time [4].

There is support for such alterations in coral community structure at some reef sites; massive coral species dominated following the 1998 bleaching event on Okinawan reefs [101], and a shift from an Acropora-dominated assemblage to a Porites-dominated assemblage was observed in French Polynesia [110]. Shifts of this nature will have wide-ranging impacts on reef functioning, habitat provision and the ability of reefs to remain within a positive carbonate accretion state. Branching coral genera, primarily Acropora, can drive the highest carbonate production rates across reef sites with varying coral community composition, particularly where conditions for growth are favourable (Fig. 2b [111]). However, in more challenging conditions, where reefs are recovering from disturbance, or have undergone regimes shifts away from coral domination, massive corals often considered as 'framework builders' appear critical in the maintenance of a positive carbonate budget [112]. Therefore, the recent ecological trajectory and disturbance history of a reef site should be considered in determining the degree to which the coral species present are 'optimal' for maintaining a positive accretionary state.

More recently, the global consistency in bleaching susceptibility between genera has been questioned, partially due to geographic biases in surveys during and post-bleaching events [113], but also as response diversity is emerging across successive bleaching events [21]. The susceptibility of Acropora and Montipora declined between bleaching events in French Polynesia [99], with similar reductions in the mortality of Acropora from the Persian Gulf region [50], whilst a reversal in susceptibility for Acropora and Pocillopora between the 1998 and 2010 bleaching events is suggested to have occurred in Singapore [114]. These findings emphasise that the resistance of corals to thermal stress varies across taxa with increasing 'experience' of thermal stress, and that responses 
from an isolated bleaching event may differ from those observed under frequent repeated bleaching events [66, 106].

Branching coral species considered 'bleaching susceptible' are also capable of the highest contributions to growth and recovery following thermal stress events. Where reef recovery following bleaching events has been observed within the Indo-Pacific, it is often driven by growth of Acropora and Pocillopora and additional coral species with life history strategies that have been categorised as 'competitive' or 'weedy' $[100,115,116]$. However, in some instances, extremely rapid coral recovery ( $<1$ year) following bleaching events has been observed via regenerative growth of remnant coral tissue in both branching and massive coral species, a phenomenon termed the Phoenix effect $[117,118]$.

Over longer timeframes, the frequency and severity of future bleaching episodes may determine which coral genera are 'winners' or 'losers'. If bleaching events are infrequent and mild, species with rapid growth and recovery rates will be favoured. As events become more severe and more frequent, 'stress-tolerance' and the ability to resist bleaching, rather than recover rapidly in its aftermath, become increasingly important [119]. If the global mean projected timing of Annual Severe Bleaching (ASB) by mid-century becomes a reality, experimental evidence from Caribbean coral species suggests that this cumulative impact of higher frequency events may cause unexpected alterations in thermal tolerance between species [106]. The presence of bleaching resistant coral species is a reef resilience indicator identified by reef scientists and managers as having a high feasibility for implementation [37]; importantly however, the composition of this group of resilient species may change as global thermal conditions approach and reach ASB.

\section{Microbiome Resilience}

The processes facilitating the growth and persistence of coral reefs include a diverse range of cellular-level exchanges between prokaryotic and eukaryotic organisms. Corals are among the first organisms to be considered as interdependent host-microbe 'meta-organisms', largely due to a focus on their endosymbiotic algae, but research is increasingly advancing the role of the wider coral 'microbiome', composed of bacteria, eukaryotic microbes and viruses, in the functioning of the overall system [25]. Thermal resilience is therefore related to the physiological and genetic variation present in all partners: the coral host, the dinoflagellate algae and associated microorganisms, and this complexity confers a degree of additional capacity to adapt or acclimate (potentially rapidly) by altering elements of the symbiosis $[11,25,120]$.

The concept that corals altered the composition of their algal symbiont communities in response to thermal stress was initially formalised as the 'adaptive bleaching hypothesis' [121], which has since generated a considerable body of both supportive evidence and criticism [122]. It has also facilitated increased understanding of the flexibility within the host-algal symbiosis and diversity within Symbiodinium algae. First characterised as a single global species: Symbiodinium microadriaticum [123], Symbiodinium has since been further validated and classified into nine phylogenetic clades (A-I), of which four: A, B, C and D, commonly occur within coral symbioses $[124,125]$. There is further genetic diversity in that each clade contains multiple 'types' commonly characterised on the basis of ITS2 variation [126]; several of these types have been suggested to satisfy the ecological species concept and have therefore been described as separate species [127].

The host-algal symbiosis displays varying degrees of fidelity: within some coral, notably Porites spp., associations are highly specific, and maternally inherited, and whilst a majority $(\sim 60-80 \%)$ of coral species host one clade of Symbiodinium [128, 129], others simultaneously contain multiple clades within colonies [130]. Increases in thermal resilience can therefore potentially come via 'shuffling' of symbiont clades within a colony, or 'switching' - the acquisition of a 'new' clade from the surrounding environment. Certain highly differentiated clade D Symbiodinium (e.g. type D1-4 S. trenchii [96]) are common in warm, turbid habitats and are pan-tropical in their distribution. Their prevalence is higher within coral populations growing in naturally warmer microhabitats [131], and in more variable and thermally extreme reef lagoon/tide pool environments [132].

The ability of clade D symbionts to increase coral holobiont thermal tolerance by $1-2{ }^{\circ} \mathrm{C}$, relative to thermally sensitive clades [68], led to research focus on this clade as candidates for adaptive thermotolerance mechanisms. There is evidence, both at reef scales and within individual colonies, of corals switching to clade D symbiotic partners following bleaching events $[120,133]$. However, the enhanced thermal resilience of clade D Symbiodinium appears to come with an energetic cost, exhibited in reduced coral growth rates [134], which has led to suggestions that rather than conferring longterm resilience, these symbionts are transient opportunists [135], bordering on parasitic [136], which exploit thermally stressed corals pre-and-post-bleaching event. The trade-offs between thermal sensitivity, growth impact and the time taken for a potential 'super-symbiont' with characteristics similar to clade D1 to become dominant on reef have been modelled over a 90-year time-scale [31] and show that both greenhouse gas emission levels and coral competitive ability with macroalgae strongly affect the ecosystem benefits of thermally tolerant coral symbionts within the Caribbean. It is also now apparent that thermotolerance is not restricted to clade D: within the Perisan Gulf, genetic differentiation in clade C3 Symbiodinium is such that a new species; Symbiodinium thermophilum has been described, whilst Symbiodinium C15 are suggested to contribute to the observed resistance of Porites spp. to thermal stress [137]. Aside from inter-clade differences, a static Symbiodinium partner can adapt to higher 
temperatures via natural selection over successive generations, and this ability has been demonstrated between local populations on the GBR [51], and over 2.5 years of laboratory thermal selection [138].

Universally, investigations into the coral bacterial microbiome have revealed enormous diversity in composition [139-141]. Understanding of coral-microbial interactions is expanding rapidly, facilitated by novel genomic sequencing techniques, and focus is shifting from their identification as disease pathogens, to recognition of the symbiotic aspects of their presence. The microbial community can be divided into a 'core' microbiome that is temporally stable and a more dynamic transient community [25, 142]. The core bacterial community has been implicated in a range of functional roles, particularly sulphur, carbon and nitrogen cycling, and shifts observed in the composition of this community following environmental stress are consistent with an involvement in coral holobiont recovery $[143,144]$. A subset of microbial symbionts have recently been characterised as 'beneficial microorganisms for corals', conceptually similar to 'coral probiotics', in that their presence within corals could potentially prevent bleaching during thermal stress events [145]. Where changes in coral microbial communities do result in acclimatisation to higher SST regimes, beneficial microbial traits can be conserved via vertical transmission of the altered microbiome, facilitating coral transgenerational acclimatisation [146]. These properties support the contention that the diversity and composition of the microbial microbiome are important indicators of coral resilience to climate change [25, 142].

\section{Synthesis}

A possible criticism of the value of focusing on coral reef resilience to bleaching events is that, whatever the processes involved, they do not appear to be increasing in effectiveness - reefs have repeatedly bleached since the first pantropical 1998 event, with the most recent 2014-2017 the most extended, widespread and severe event recorded to date [5, 19]. Nonetheless, there are strands of evidence that coral reefs are becoming more resilient to thermal stress - application of a preindustrial (1900-1919) climatology to GCMs over the 1900-2100 timeframe slightly over-predicts present-day bleaching frequency [28], indicating that including an adaptive coral response is required to correct modelled coral bleaching frequency. A more recent high-resolution global coral bleaching database also found that the annual maximum DHW of coral reefs which had the highest probability of bleaching (>90\%) increased more rapidly over time than the annual maximum DHW for all coral reefs examined [113], again suggesting that acclimatisation to thermal stress is taking place (although this was opposite for the Caribbean, indicating a progressive reduction in thermal resilience). At the reef scale, there are several recent studies showing coral 'sensitivity' to bleaching decreasing across repeated thermal stress events [12, 99, 114].

Coral reefs are ecosystems which are subjected to naturally high levels of disturbance, which contain species adapted to rapid recovery, and exhibit a variety of processes facilitating recovery $[114,147]$. The key question is not whether this resilience or adaptive capacity exists on coral reefs, but whether it can keep pace with the predicted increase in the return frequency of thermal stress events resulting in global coral beaching. Even if coral reef resilience or adaptive capacity is overwhelmed by the return frequency of thermal stress at some point during the present century as predicted by GCMs (and the present global carbon dioxide emissions trajectory), this will not occur simultaneously across all reefs [29], and the identification and protection of the most resilient locations is justified to maintain ecosystem goods and services for human populations inhabiting tropical coastal areas for as long as possible. The most likely outcome is that coral reefs will adapt to an extent, but may be increasingly altered in both their composition and distribution relative to present-day reefs. These 'future-reefs' might themselves be highly resistant to thermal stress, as the dominant species emerging will be competitive under warmer, potentially more variable thermal regimes. This can be conceptualised as a regime shift within the broader ecological resilience framework; for reefs of the Caribbean, this shift might likely be to an algaldominated state, whilst for a majority of Indo-Pacific reefs, it remains to be seen if alternative stable states emerge, or if reefs continue broadly within their present state but become increasingly 'mediocre' [148], or dominated by a reduced subset of coral species.

The sexual generation time for most tropical reef-forming coral species is 4-8 years [149]; therefore, coral genetic adaptation rates operate on time-scales which are too slow to respond to current climate change impacts [150]. However, there are several processes which can influence coral thermal resilience that operate on sufficiently rapid time-scales to influence response to future high frequency bleaching events (Fig. 3). These primarily occur within the coral symbiotic partners, and to an extent via selective mortality and epigenetic factors. There is thus a degree of mis-match in the spatial scales at which resilience processes operating over fast timescales occur and the generally larger scales of potential management interventions. Few realistic management options presently exist at sub-colony spatial scales, although numerous options within 'assisted evolution' approaches have been outlined and suggested to merit more serious consideration [151]. Aside from direct intervention, seeking to identify reef locations with the most advantageous characteristics and maximising the time for adaptive mechanisms to take place prior to even greater disturbances will increase the likelihood of corals 'keeping pace' with climate change. The identification of resilient reef areas at spatial sales relevant to 
Fig. 3 An illustration of the relationship between the timescales ( $x$-axis) and spatial scales $(y$-axis) at which mechanisms contributing to coral resilience operate. Extrinsic factors with the ability to influence the thermal stress experienced by corals during bleaching events are shown across spatial scales on the righthand axis. Coral reefs have experienced a disturbance regime where major disturbances broadly occur at decadal frequencies (existing bleaching paradigmblue lines). Fewer resilience factors are likely to operate as a future shift to annual severe bleaching (ASB-red lines) occurs

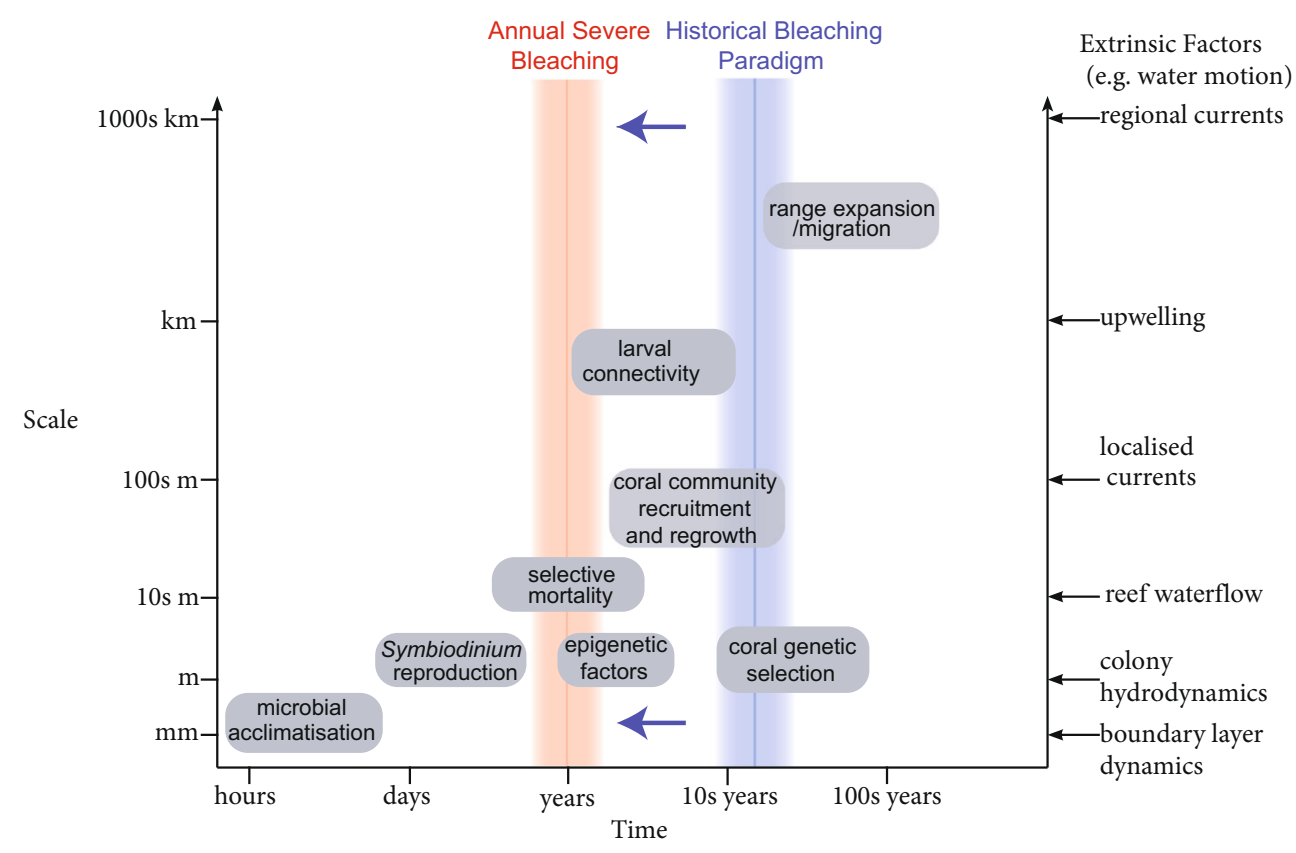

management under predicted climate change impacts requires the adoption of novel techniques, and potentially, consideration of protective measures for reefs thus far not considered as conservation priorities. These reefs may be close to human population centres [152], within the nearshore turbid-zone [153], or have previously been considered as degraded [154].

Where spatially explicit reef assessments incorporating multiple resilience factors have been carried out, they have found high spatial variability in resilience metrics [36] and have revealed resilience potential in unexpected locations [47]. Locations with high resilience may not be within existing marine protected areas (MPAs). MPAs are designated across a diverse range of potential objectives, and where explicit criteria are involved in selection, they are likely to be divergent from resilience criteria. Whatever the goals of protection, MPAs are perhaps the foremost management 'tool' utilised across global reef provinces. There are conflicting reports within the literature on the impact of MPA designation on coral resilience. Early studies [84] did not find any difference in coral reef health between protected and non-protected sites. MPA designation is insufficient-MPA performance depends on characteristics including sufficient size, time under protection, compliance with regulations etc. Yet, in the most comprehensive study to date of the impacts of the most recent global bleaching event on the GBR, local protective status conferred no resistance to bleaching [5]. However, previous convincing evidence of positive MPA contribution to coral reef resilience also comes from studies on the GBR, and within the Caribbean, suggesting protection should assist to promote post-bleaching recovery $[155,156]$.

An additional, or alternative management approach to MPA designation for sites identified with resilience potential may be to work in keeping key variables with demonstrated links to ecosystem status, within an 'acceptable range' of values [157, 158, 159]. This could be conceived as a 'safeoperating space' for reefs [158, 159], enabling on-going processes of adaptation and ecosystem reorganisation following disturbances to occur. Climate change impacts may require increasing acceptance of change and alteration on coral reefs, but a focus on identifying, understanding and supporting reef resilience, concurrent with co-ordinated action at a global scale to reduce carbon dioxide emissions, offers the most realistic means of maintaining reef ecosystem goods and services into the future.

Acknowledgements The authors would like to acknowledge support from the UK government Darwin Initiative Grant 19-027, and from the Bertarelli Foundation in facilitating the research upon which much of the present work is based. We would also like to thank Peter Mumby, and an anonymous reviewer for their work and comments to improve this manuscript.

\section{Compliance with Ethical Standards}

Conflict of Interest On behalf of all authors, the corresponding author states that there is no conflict of interest.

Open Access This article is distributed under the terms of the Creative Commons Attribution 4.0 International License (http:// creativecommons.org/licenses/by/4.0/), which permits unrestricted use, distribution, and reproduction in any medium, provided you give appropriate credit to the original author(s) and the source, provide a link to the Creative Commons license, and indicate if changes were made.

\section{References}

1. Gardner T, Cote I, Gill J, Grant A, Watkinson A. Long-term region-wide declines in Caribbean coral reefs. Science. 2003;301(5635):958-60. https://doi.org/10.1126/science. 1086050 . 
2. De'ath G, Fabricius KE, Sweatman H, Puotinen M. The 27-year decline of coral cover on the great barrier reef and its causes. Proc Natl Acad Sci U S A. 2012;109(44):17995-9. https://doi.org/10. 1073/pnas.1208909109.

3. Pandolfi JM, Bradbury RH, Sala E, Hughes TP. Global trajectories of the long-term decline of coral reef ecosystems. Science. 2003;301(5635):955-7. https://doi.org/10.1126/science.1085706.

4. Hughes TP, Baird AH, Bellwood DR, Card M. Climate change, human impacts, and the resilience of coral reefs. Science. 2003;301(5635):929-33. https://doi.org/10.1126/science. 1085046.

5. Hughes TP, Kerry JT, Álvarez-Noriega M, Álvarez-Romero JG, Anderson KD, Baird AH, et al. Global warming and recurrent mass bleaching of corals. Nature. 2017;543(7645):373-7. https:// doi.org/10.1038/nature21707.

6. Anthony KRN. Coral reefs under climate change and ocean acidification: challenges and opportunities for management and policy. Annu Rev Environ Resour. 2016;41(1):59-81. https://doi.org/ 10.1146/annurev-environ-110615-085610.

7. Hoegh-Guldberg O, Mumby PJ, Hooten AJ, Steneck RS, Greenfield P, Gomez E, et al. Coral reefs under rapid climate change and ocean acidification. Science. 2007;318(5857):173742. https://doi.org/10.1126/science.1152509.

8. Baird AH, Bhagooli R, Ralph PJ, Takahashi S. Coral bleaching: the role of the host. Trends Ecol Evol. 2009;24(1):16-20. https:// doi.org/10.1016/j.tree.2008.09.005.

9. Weis VM. Cellular mechanisms of cnidarian bleaching: stress causes the collapse of symbiosis. J Exp Biol. 2008;211(19): 3059-66. https://doi.org/10.1242/jeb.009597.

10. Wilkinson CR. Global and local threats to coral reef functioning and existence: review and predictions. Mar Freshw Res. 1999;50(8):867. https://doi.org/10.1071/MF99121.

11. Baker AC, Glynn PW, Riegl B. Climate change and coral reef bleaching: an ecological assessment of long-term impacts, recovery trends and future outlook. Estuar Coast Shelf Sci. 2008;80(4): 435-71. https://doi.org/10.1016/j.ecss.2008.09.003.

12. McClanahan TR. Changes in coral sensitivity to thermal anomalies. Mar Ecol Prog Ser. 2017;570:71-85. https://doi.org/10.3354/ meps12150.

13. Obura DO. Reef corals bleach to resist stress. Marine Poll Bull. 2008;58:206-12.

14. Brown BE. Coral bleaching: causes and consequences. Coral Reefs. 1997;16(0):S129-38. https://doi.org/10.1007/ s003380050249.

15. Glynn PW, Maté JL, Baker AC. Coral bleaching and mortality in Panama and Ecuador during the 1997-1998 el Niño-southern oscillation event: spatial/temporal patterns and comparisons with the 1982-1983 event. Bull Mar Sci. 2001;69:79-109.

16. Goreau T, McClanahan T, Hayes R. Conservation of coral reefs after the 1998 global bleaching event. Conserv Biol. 2000;14(1): 5-15. https://doi.org/10.1046/j.1523-1739.2000.00011.x.

17. Moore JAY, Bellchambers LM, Depczynski MR, Evans RD, Evans SN, Field SN, et al. Unprecedented mass bleaching and loss of coral across $12^{\circ}$ of latitude in Western Australia in 2010 11. PLoS One. 2012;7:e51807.

18. Eakin CM, Liu G, Gomez AM, De La Cour JL, Heron SF, Skirving WJ, Geiger EF, Marsh BL, Tirak KV, Strong AE. Ding, dong, the witch is dead (?) - three years of global coral bleaching 2014-2017. Reef Encounter. 2017;32(1):33-8. http:// coralreefs.org/wp-content/uploads/2014/03/Reef-EncounterAugust-2017-FINAL-Lo-Res.pdf.

19. Kayanne H. Validation of degree heating weeks as a coral bleaching index in the northwestern Pacific. Coral Reefs. 2017;36(1):63-70. https://doi.org/10.1007/s00338-016-1524-y.
20. Normile D. El Nino's warmth devastating reefs worldwide. Science. 2016;352(6281):15-6. https://doi.org/10.1126/science. 352.6281.15.

21. Hoogenboom MO, Frank GE, Chase TJ, Jurriaans S, ÁlvarezNoriega M, Peterson K, et al. Environmental drivers of variation in bleaching severity of Acropora species during an extreme thermal anomaly. Glob Chang Biol. 2017;11:2251-65.

22. van Hooidonk R, Maynard JA, Planes S. Temporary refugia for coral reefs in a warming world. Nat Clim Chang. 2013;3:1-4.

23. Hoegh-Guldberg O. Climate change, coral bleaching and the future of the world's coral reefs. Ma Freshwater Res. 1999;50(8): 839-66. https://doi.org/10.1071/MF99078.

24. West JM, Salm RV. Resistance and resilience to coral bleaching: implications for coral reef conservation and management. Conserv Biol. 2003;17(4):956-67. https://doi.org/10.1046/j.1523-1739. 2003.02055.x.

25. Putnam HM, Barott KL, Ainsworth TD, Gates RD. The vulnerability and resilience of reef-building corals. Curr Biol. 2017;27(11):R528-40. https://doi.org/10.1016/j.cub.2017.04. 047.

26. Sheppard C. Predicted recurrences of mass coral mortality in the Indian Ocean. Nature. 2003;425(6955):294-7. https://doi.org/10. 1038/nature01987.

27. Done TJ. Coral community adaptability to environmental change at the scales of regions, reefs and reef zones. Am Zool. 1999;39(1):66-79. https://doi.org/10.1093/icb/39.1.66.

28. Logan CA, Dunne JP, Eakin CM, Donner SD. Incorporating adaptive responses into future projections of coral bleaching. Glob Change Biol. 2013;20:125-39.

29. Van Hooidonk R, Maynard J, Tamelander J, Gove J, Ahmadia G, Raymundo L, Williams G, Heron SF, Planes S. Local-scale projections of coral reef futures and implications of the Paris Agreement. Sci Rep. 2016;6:39666. https://doi.org/10.1038/ srep39666.

30. Ortiz JC, González-Rivero M, Mumby PJ. Can a thermally tolerant symbiont improve the future of Caribbean coral reefs? Glob Change Biol. 2012;19:273-81.

31. Ortiz JC, González-Rivero M, Mumby PJ. An ecosystem-level perspective on the host and symbiont traits needed to mitigate climate change impacts on Caribbean coral reefs. Ecosystems. 2013;17:1-13.

32. Edmunds PJ, Burgess SC, Putnam HM, Baskett ML, Bramanti L, Fabina NS, et al. Evaluating the causal basis of ecological success within the scleractinia: an integral projection model approach. Mar Biol. 2014;161(12):2719-34. https://doi.org/10.1007/s00227014-2547-y.

33. Edmunds PJ, Adjeroud M, Baskett ML, Baums IB, Budd AF, Carpenter RC, et al. Persistence and change in community composition of reef corals through present, past, and future climates. PLoS One. 2014;9(10):e107525. https://doi.org/10.1371/journal. pone. 0107525 .

34. Taylor KE, Stouffer RJ, Meehl GA. An overview of CMIP5 and the experiment design. Bull Amer Meteor Soc. 2012;93(4):48598. https://doi.org/10.1175/BAMS-D-11-00094.1.

35. Kwiatkowski L, Halloran PR, Mumby PJ, Stephenson DB. What spatial scales are believable for climate model projections of sea surface temperature? Clim Dyn. 2013;43:1483-96.

36. Maynard JA, Marshall PA, Johnson JE, Harman S. Building resilience into practical conservation: identifying local management responses to global climate change in the southern great barrier reef. Coral Reefs. 2010;29(2):381-91. https://doi.org/10.1007/ s00338-010-0603-8.

37. McClanahan TR, Donner SD, Maynard JA, MacNeil MA, Graham NAJ, Maina J, et al. Prioritizing key resilience indicators to support coral reef Management in a Changing Climate. PLoS 
One. 2012;7(8):e42884. https://doi.org/10.1371/journal.pone. 0042884 .

38. Anthony KRN, Marshall PA, Abdulla A, Beeden R, Bergh C, Black R, et al. Operationalizing resilience for adaptive coral reef management under global environmental change. Glob Change Biol. 2014;21:48-61.

39. Nystrom M, Folke C, Moberg F. Coral reef disturbance and resilience in a human-dominated environment. Trends Ecol Evol. 2000;10:413-7.

40. Grimsditch GD, Salm RV. Coral reef resilience and resistance to bleaching. Gland: The World Conservation Union (IUCN); 2006.

41. Standish RJ, Hobbs RJ, Mayfield MM, Bestelmeyer BT, Suding $\mathrm{KN}$, Battaglia LL, et al. Resilience in ecology: abstraction, distraction, or where the action is? Biol Conserv. 2014;177:43-51. https://doi.org/10.1016/j.biocon.2014.06.008.

42. Mumby PJ, Hastings A, Edwards HJ. Thresholds and the resilience of Caribbean coral reefs. Nature. 2007;450(7166):98-101. https://doi.org/10.1038/nature06252.

43. Mumby PJ, Chollett I, Bozec Y-M, Wolff NH. Ecological resilience, robustness and vulnerability: how do these concepts benefit ecosystem management? Curr Opin Environ Sustain. 2014;7:227. https://doi.org/10.1016/j.cosust.2013.11.021.

44. Obura DO, Grimsditch GD. Resilience assessment of coral reefs: assessment protocol for coral reefs, focusing on coral bleaching and thermal stress. Gland: IUCN; 2009.

45. Graham NAJ, Jennings S, MacNeil MA, Mouillot D, Wilson SK. Predicting climate-driven regime shifts versus rebound potential in coral reefs. Nature. 2015;00:1-17.

46. Albright R, Anthony KRN, Baird M, Beeden R, Byrne M, Collier $\mathrm{C}$, et al. Journal of environmental management. J Environ Manag. 2016;182:641-50. https://doi.org/10.1016/j.jenvman.2016.07. 038.

47. Maynard JA, McKagan S, Raymundo L, Johnson S, Ahmadia GN, Johnston L, et al. Assessing relative resilience potential of coral reefs to inform management. Biol Conserv. 2015;192:10919. https://doi.org/10.1016/j.biocon.2015.09.001.

48. Purkis SJ, Rowlands GP, Riegl BM, Renaud PG. The paradox of tropical karst morphology in the coral reefs of the arid Middle East. Geology. 2010;38(3):227-30. https://doi.org/10.1130/ G30710.1.

49. Riegl BM, Purkis SJ, Al-Cibahy AS, Abdel-Moati MA, HoeghGuldberg O. Present limits to heat-adaptability in corals and population-level responses to climate extremes. PLoS One. 2011;6(9):e24802. https://doi.org/10.1371/journal.pone.0024802.

50. Coles SL, Brown BE. Coral bleaching - capacity for acclimatization and adaptation. Adv Mar Biol. 2003;46:183-223. https://doi. org/10.1016/S0065-2881(03)46004-5.

51. Howells EJ, Beltran VH, Larsen NW, Bay LK, Willis BL, van Oppen MJH. Coral thermal tolerance shaped by local adaptation of photosymbionts. Nat Clim Chang. 2011;2:1-5.

52. Coles SL, Riegl BM. Thermal tolerances of reef corals in the Gulf: a review of the potential for increasing coral survival and adaptation to climate change through assisted translocation. Marine Poll Bull. 2013;72(2):323-32. https://doi.org/10.1016/j.marpolbul. 2012.09.006.

53. Fine $\mathrm{M}$, Gildor H, Genin A. A coral reef refuge in the Red Sea. Glob Change Biol. 2013;19(12):3640-7. https://doi.org/10.1111/ gcb.12356.

54. Krueger T, Horwitz N, Bodin J, Giovani M-E, Escrig SP, Meibom A, et al. Common reef-building coral in the northern Red Sea resistant to elevated temperature and acidification. $\mathrm{R}$ Soc open sci. 2017;4(5):170038. https://doi.org/10.1098/rsos.170038.

55. Riegl B, Piller WE. Possible refugia for reefs in times of environmental stress. Int J Earth Sci (Geol Rundsch). 2003;92(4):520-31. https://doi.org/10.1007/s00531-003-0328-9.
56. Buddemeier RW, Kleypas JA, Aronson RB. Potential contributions of climate change to stresses on coral reef ecosystems. Coral reefs and global climate change. Virginia: Pew Center on Global Climate Change; 2004.

57. Hyndes GA, Heck KL Jr, Vergés A, Harvey ES, Kendrick GA, Lavery PS, et al. Accelerating Tropicalization and the transformation of temperate seagrass meadows. Bioscience. 2016;66(11): 938-48. https://doi.org/10.1093/biosci/biw111.

58. Vergés A, Doropoulos C, Malcolm HA, Skye M, Garcia-Pizá M, Marzinelli EM, et al. Long-term empirical evidence of ocean warming leading to tropicalization of fish communities, increased herbivory, and loss of kelp. Proc Natl Acad Sci U S A. 2016;113(48):13791-6. https://doi.org/10.1073/pnas. 1610725113.

59. Hoegh-Guldberg O, Hughes L, McIntyre S, Lindenmayer DB, Parmesan C, Possingham HP, et al. Ecology: assisted colonization and rapid climate change. Science. 2008;321(5887):345-6. https://doi.org/10.1126/science.1157897.

60. Ayre DJ, Hughes TP. Climate change, genotypic diversity and gene flow in reef-building corals. Ecol Lett. 2004;7(4):273-8. https://doi.org/10.1111/j.1461-0248.2004.00585.x.

61. Thomas L, Kennington WJ, Evans RD, Kendrick GA, Stat M. Restricted gene flow and local adaptation highlight the vulnerability of high-latitude reefs to rapid environmental change. Glob Chang Biol. 2017;23(6):2197-205. https://doi.org/10.1111/gcb. 13639.

62. Boyd PW, Cornwall CE, Davison A, Doney SC, Fourquez M, Hurd CL, et al. Biological responses to environmental heterogeneity under future ocean conditions. Glob Chang Biol. 2016;22(8):2633-50. https://doi.org/10.1111/gcb.13287.

63. van Hooidonk R, Maynard JA, Liu Y, Lee S-K. Downscaled projections of Caribbean coral bleaching that can inform conservation planning. Glob Change Biol. 2015;21(9):3389-401. https://doi. org $10.1111 / \mathrm{gcb} .12901$.

64. Thompson DM, van Woesik R. Corals escape bleaching in regions that recently and historically experienced frequent thermal stress. Proc R Soc Lond. Biol Sci. 2009;276(1669):2893-901. https:// doi.org/10.1098/rspb.2009.0591.

65. McClanahan TR, Ateweberhan M. Effects of climate and seawater temperature variation on coral bleaching and mortality. Ecol Monogr. 2007;77(4):503-25. https://doi.org/10.1890/06-1182.1.

66. Williams GJ, Knapp IS, Maragos JE, Davy SK. Modeling patterns of coral bleaching at a remote Central Pacific atoll. Marine Poll Bull. 2010;60(9):1467-76. https://doi.org/10.1016/j.marpolbul. 2010.05.009.

67. Ainsworth TD, Heron SF, Ortiz JC, Mumby PJ. Climate change disables coral bleaching protection on the great barrier reef. Science. 2016;352(6283):338-42. https://doi.org/10.1126/ science.aac7125.

68. Berkelmans R, De'ath G, Kininmonth S, Skirving WJ. A comparison of the 1998 and 2002 coral bleaching events on the great barrier reef: spatial correlation, patterns, and predictions. Coral Reefs. 2004;23(1):74-83. https://doi.org/10.1007/s00338-0030353-y.

69. Wall M, Putchim L, Schmidt GM, Jantzen C, Khokiattiwong S, Richter C. Large-amplitude internal waves benefit corals during thermal stress. Proc R Soc Lond: Biol Sci. 2014;282:20140650-0.

70. Chou LM. Southeast Asian Reefs-Status update: Cambodia, Indonesia, Malaysia, Philippines, Singapore, Thailand and Viet Nam. In: Wilkinson C, editor. Status of coral reefs of the world. Townsville: Australlian Institute of Marine; 2000. pp. 117-29.

71. Schuttenberg HZ. Coral bleaching: causes, consequences, and response. Selected Papers presented at the Ninth International Coral Reef Symposium on "Coral Bleaching: Assessing and Linking Ecological and Socioeconomic Impacts, Future Trends and Mitigation Planning” Coastal Management Report \#2230, 
Coastal Resources Center, University of Rhode Island; 2001. pp. 102.

72. McClanahan TR, Maina J, Moothien-Pillay R. Effects of geography, taxa, water flow, and temperature variation on coral bleaching intensity in Mauritius. Mar Ecol Prog Ser. 2005;298:131-42. https://doi.org/10.3354/meps298131.

73. Chollett I, Mumby PJ, Cortes J. Upwelling areas do not guarantee refuge for coral reefs in a warming ocean. Mar Ecol Prog Ser. 2010;416:47-56. https://doi.org/10.3354/meps08775.

74. Wolanski E, Andutta F, Deleersnijder E, Li Y, Thomas CJ. The Gulf of Carpentaria heated Torres Strait and the northern great barrier reef during the 2016 mass coral bleaching event. Estuar Coast Shelf S. 2017;194:172-81. https://doi.org/10.1016/j.ecss. 2017.06.018.

75. D’Croz L, Maté JL. Experimental responses to elevated water temperature in genotypes of the reef coral Pocillopora damicornis from upwelling and non-upwelling environments in Panama. Coral Reefs. 2004;23(4):473-83. https://doi.org/10.1007/s00338004-0397-7.

76. Otis DB, Carder KL, English DC, Ivey JECDOM. Transport from the Bahamas banks. Coral Reefs. 2004;23(1):152-60. https://doi. org/10.1007/s00338-003-0356-8.

77. Obura DO. Resilience and climate change: lessons from coral reefs and bleaching in the western Indian Ocean. Estuar Coast Shelf S. 2005;63(3):353-72. https://doi.org/10.1016/j.ecss.2004. 11.010 .

78. Wagner DE, Kramer P, van Woesik R. Species composition, habitat, and water quality influence coral bleaching in southern Florida. Mar Ecol Prog Ser. 2010;408:65-78. https://doi.org/10. 3354/meps08584.

79. Morgan KM, Perry CT, Johnson JA, Smithers SG. Nearshore turbid-zone corals exhibit high bleaching tolerance on the great barrier reef following the 2016 ocean warming event. Front Mar Sci. 2017;4:59.

80. Anthony K. Coral suspension feeding on fine particulate matter. J Exp Mar Biol Ecol. 1999;232(1):85-106. https://doi.org/10.1016/ S0022-0981(98)00099-9.

81. Anthony K. Enhanced energy status of corals on coastal, highturbidity reefs. Mar Ecol Prog Ser. 2006;319:111-6. https://doi. org/10.3354/meps319111.

82. Hongo C, Yamano H. Species-specific responses of corals to bleaching events on Anthropogenically turbid reefs on Okinawa Island, Japan, over a 15-year period (1995-2009). PLoS One. 2013;8(4):e60952. https://doi.org/10.1371/journal.pone.0060952.

83. Cacciapaglia C, van Woesik R. Climate-change refugia: shading reef corals by turbidity. Glob Chang Biol. 2015;22:1145-54.

84. Hodgson G. A global assessment of human effects on coral reefs. Marine Poll Bull. 1999;38(5):345-55. https://doi.org/10.1016/ S0025-326X(99)00002-8.

85. Crane NL, Nelson P, Abelson A, Precoda K, Rulmal J, Bernardi G, et al. Atoll-scale patterns in coral reef community structure: human signatures on Ulithi atoll, Micronesia. PLoS One. 2017;12(5): e0177083. https://doi.org/10.1371/journal.pone.0177083.

86. Sandin SA, Smith JE, DeMartini EE, Dinsdale EA, Donner SD, Friedlander AM, et al. Baselines and degradation of coral reefs in the northern Line Islands. PLoS One. 2008;3(2):e1548. https://doi. org/10.1371/journal.pone.0001548.

87. Gilmour JP, Smith LD, Heyward AJ, Baird AH. Recovery of an isolated coral reef system following severe disturbance. Science. 2013;340(6128):69-71. https://doi.org/10.1126/science.1232310.

88. Sheppard C, Harris A, Sheppard A. Archipelago-wide coral recovery patterns since 1998 in the Chagos archipelago, central Indian Ocean. Mar Ecol Prog Ser. 2008;362:109-17. https://doi.org/10. 3354/meps07436.
89. Magris RA, Treml EA, Pressey RL, Weeks R. Integrating multiple species connectivity and habitat quality into conservation planning for coral reefs. Ecography. 2015;39:649-64.

90. Baums IB, Paris CB, Ridgwell A, Kessler WS, Hendy EJ, Wood S. El Nino and coral larval dispersal across the eastern Pacific marine barrier. Nat Commun. 2016;7:1-11.

91. Hughes TP, Graham NAJ, Jackson JBC, Mumby PJ, Steneck RS. Rising to the challenge of sustaining coral reef resilience. Trends Ecol Evol. 2010;25(11):633-42. https://doi.org/10.1016/j.tree. 2010.07.011.

92. Nyström M, Graham N, Lokrantz J, Norström AV. Capturing the cornerstones of coral reef resilience: linking theory to practice. Coral Reefs. 2008;27(4):795-809. https://doi.org/10.1007/ s00338-008-0426-z.

93. Mumby PJ, Elliott IA, Eakin CM, Skirving W, Paris CB, Edwards $\mathrm{HJ}$, et al. Reserve design for uncertain responses of coral reefs to climate change. Ecol Lett. 2010;14:132-40.

94. Cameron KA, Harrison PL. Patterns of scleractinian coral recruitment at Lord Howe Island, an isolated subtropical reef off eastern Australia. Coral Reefs. 2016;35(2):555-64. https://doi.org/10. 1007/s00338-016-1414-3.

95. Doropoulos C, Ward S, Roff G, González-Rivero M, Mumby PJ. Linking demographic processes of juvenile corals to benthic recovery trajectories in two common reef habitats. PLoS One. 2015;10(5):e0128535. https://doi.org/10.1371/journal.pone. 0128535 .

96. Manikandan B, Ravindran J, Vidya PJ, Shrinivasu S, Manimurali $\mathrm{R}$, Paramasivam K. Resilience potential of an Indian Ocean reef: an assessment through coral recruitment pattern and survivability of juvenile corals to recurrent stress events. Environ Sci Pollut Res. 2017:1-12. https://doi.org/10.1007/s11356-017-8772-4.

97. Lam VYY, Doropoulos C, Mumby PJ. The influence of resiliencebased management on coral reef monitoring: a systematic review. PLoS One. 2017;12(2):e0172064. https://doi.org/10.1371/journal. pone. 0172064.

98. Tkachenko KS, Soong K. Marine environmental research. Mar Environ Res. 2017;127:112-25. https://doi.org/10.1016/j. marenvres.2017.04.003.

99. Pratchett MS, McCowan D, Maynard JA, Heron SF. Changes in bleaching susceptibility among corals subject to ocean warming and recurrent bleaching in Moorea, French Polynesia. PLoS One. 2013;8(7):e70443. https://doi.org/10.1371/journal.pone.0070443.

100. Pisapia C, Burn D, Yoosuf R, Najeeb A, Anderson KD, Pratchett MS. Coral recovery in the central Maldives archipelago since the last major mass-bleaching in 1998. Sci Rep. 2016;6. https://doi. org/10.1038/srep34720.

101. Loya Y, Sakai K, Yamazato K, Nakano Y, Sambali H, van Woesik R. Coral bleaching: the winners and the losers. Ecol Lett. 2001;4(2):122-31. https://doi.org/10.1046/j.1461-0248.2001. 00203.x.

102. Hoey A, Howells E, Johansen J, Hobbs J-P, Messmer V, McCowan D, et al. Recent advances in understanding the effects of climate change on coral reefs. Diversity. 2016;8(2):12. https:/ doi.org/10.3390/d8020012.

103. Carroll AG, Harrison PL, Adjeroud M. Susceptibility of coral assemblages to successive bleaching events at Moorea, French Polynesia. Mar Freshw Res. 2017;68(4):760. https://doi.org/10. 1071/MF15134.

104. Penin L, Vidal-Dupiol J, Adjeroud M. Response of coral assemblages to thermal stress: are bleaching intensity and spatial patterns consistent between events? Environ Monit Assess. 2012;185: 5031-42.

105. Thornhill DJ, Rotjan RD, Todd BD, Chilcoat GC, Iglesias-Prieto R, Kemp DW, et al. A connection between Colony biomass and death in Caribbean reef-building corals. PLoS One. 2011;6(12): e29535. https://doi.org/10.1371/journal.pone.0029535. 
106. Grottoli AG, Warner ME, Levas SJ, Aschaffenburg MD, Schoepf $\mathrm{V}$, McGinley M, et al. The cumulative impact of annual coral bleaching can turn some coral species winners into losers. Glob Chang Biol. 2014;20(12):3823-33. https://doi.org/10.1111/gcb. 12658.

107. van Woesik R, Sakai K, Ganase A, Loya Y. Revisiting the winners and the losers a decade after coral bleaching. Mar Ecol Prog Ser. 2011;434:67-76. https://doi.org/10.3354/meps09203.

108. Depczynski M, Gilmour JP, Ridgway T, Barnes H, Heyward AJ, Holmes TH, et al. Bleaching, coral mortality and subsequent survivorship on a west Australian fringing reef. Coral Reefs. 2012;32: 233-8.

109. McClanahan TR, Baird AH, Marshall PA, Toscano MA. Comparing bleaching and mortality responses of hard corals between southern Kenya and the great barrier reef. Australia Marine Poll Bull. 2004;48(3-4):327-35. https://doi.org/10.1016/j. marpolbul.2003.08.024.

110. Berumen ML, Pratchett MS. Recovery without resilience: persistent disturbance and long-term shifts in the structure of fish and coral communities at Tiahura reef, Moorea. Coral Reefs. 2006;25(4):647-53. https://doi.org/10.1007/s00338-006-0145-2.

111. Perry CT, Murphy GN, Graham NA, Wilson SK, JanuchowskiHartley FA, East HK. Remote coral reefs can sustain high growth potential and may match future sea-level trends. Sci Rep. 2015;5. https://doi.org/10.1038/srep18289.

112. Januchowski-Hartley FA, Graham NAJ, Wilson SK, Jennings S, Perry CT. Drivers and predictions of coral reef carbonate budget trajectories. Proc Royal Soc Lond B. Biol Sci. 2017;284: 20162533.

113. Donner SD, Rickbeil GJM, Heron SFA. New, high-resolution global mass coral bleaching database. PLoS One. 2017;12(4): e0175490. https://doi.org/10.1371/journal.pone.0175490.

114. Guest JR, Baird AH, Maynard JA, Muttaqin E, Edwards AJ, Campbell SJ, et al. Contrasting patterns of coral bleaching susceptibility in 2010 suggest an adaptive response to thermal stress. PLoS One. 2012;7(3):e33353. https://doi.org/10.1371/journal. pone.0033353.

115. Adjeroud M, Michonneau F, Edmunds PJ, Chancerelle Y, de Loma TL, Penin L, et al. Recurrent disturbances, recovery trajectories, and resilience of coral assemblages on a south Central Pacific reef. Coral Reefs. 2009;28(3):775-80. https://doi.org/10. 1007/s00338-009-0515-7.

116. Darling ES, Alvarez-Filip L, Oliver TA, McClanahan TR, Côté IM. Evaluating life-history strategies of reef corals from species traits. Ecol Lett. 2012;15(12):1378-86. https://doi.org/10.1111/j. 1461-0248.2012.01861.x.

117. Roff G, Bejarano S, Bozec Y-M, Nugues M, Steneck RS, Mumby PJ. Porites and the phoenix effect: unprecedented recovery after a mass coral bleaching event at Rangiroa atoll. French Polynesia Mar Biol. 2014;161(6):1385-93. https://doi.org/10.1007/s00227014-2426-6.

118. Diaz-Pulido G, McCook LJ, Dove S, Berkelmans R, Roff G, Kline DI, et al. Doom and boom on a resilient reef: climate change, algal overgrowth and coral recovery. PLoS One. 2009;4(4):e5239. https://doi.org/10.1371/journal.pone.0005239.

119. Fabina NS, Baskett ML, Gross K. The differential effects of increasing frequency and magnitude of extreme events on coral populations. Ecol Appl. 2015;25(6):1534-45. https://doi.org/10. 1890/14-0273.1.

120. Baker AC, Starger CJ, McClanahan TR, Glynn PW. Coral reefs: Corals' adaptive response to climate change. Nature. 2004;430: 741. -1

121. Buddemeier RW, Fautin DG. Coral bleaching as an adaptive mechanism. Bioscience. 1993;43(5):320-6. https://doi.org/10. 2307/1312064.
122. Hoegh-Guldberg O, Jones RJ, Ward S, Loh WK. Ecology (communication arising): is coral bleaching really adaptive? Nature. 2002;415(6872):601-2. https://doi.org/10.1038/415601a.

123. Freudenthal HD. Symbiodinium gen. Nov. and Symbiodinium Microadriaticum sp. nov., a zooxanthella: taxonomy, life cycle, and morphology. J Eukaryot Microbiol. 1962;9:45-52.

124. Coffroth MA, Santos SR. Genetic diversity of symbiotic dinoflagellates in the genus Symbiodinium. Protist. 2005;156(1):19-34. https://doi.org/10.1016/j.protis.2005.02.004.

125. LaJeunesse TC. Validation and description of Symbiodinium microadriaticum, the type species of Symbiodinium (Dinophyta). J Phycol. 2017;53:1109-14. https://doi.org/10.1111/jpy.12570.

126. Franklin EC, Stat M, Pochon X, Putnam HM, Gates RD. GeoSymbio: a hybrid, cloud-based web application of global geospatial bioinformatics and ecoinformatics for Symbiodiniumhost symbioses. Mol. Ecol Res. 2011;12:369-73.

127. LaJeunesse TC. Wham DC, Pettay DT, Parkinson JE, Keshavmurthy S, Chen CA. Ecologically differentiated stresstolerant endosymbionts in the dinoflagellate genus Symbiodinium (Dinophyceae) clade D are different species. Phycologia. 2014;53(4):305-19. https://doi.org/10.2216/13-186. 1 .

128. Goulet TL. Most scleractinian corals and octocorals host a single symbiotic zooxanthella clade. Mar Ecol Prog Ser. 2007;335:2438. https://doi.org/10.3354/meps335243.

129. Baker AC. Flexibility and specificity in coral-algal Symbiosis: diversity, ecology, and biogeography of Symbiodinium. Annu Rev Ecol Evol Syst. 2003;34(1):661-89. https://doi.org/10.1146/ annurev.ecolsys.34.011802.132417.

130. Ulstrup KE, van Oppen MJH. Geographic and habitat partitioning of genetically distinct zooxanthellae (Symbiodinium) in Acropora corals on the great barrier reef. Mol Ecol. 2003;12(12):3477-84. https://doi.org/10.1046/j.1365-294X.2003.01988.x.

131. Fabricius KE, Mieog JC, Colin PL, Idip D, van Oppen H, Identity MJ. Diversity of coral endosymbionts (zooxanthellae) from three Palauan reefs with contrasting bleaching, temperature and shading histories. Mol Ecol. 2004;13(8):2445-58. https://doi.org/10.1111/ j.1365-294X.2004.02230.x.

132. Oliver TA, Palumbi SR. Do fluctuating temperature environments elevate coral thermal tolerance? Coral Reefs. 2011;30(2):429-40. https://doi.org/10.1007/s00338-011-0721-y.

133. Jones AM, Berkelmans R, van Oppen MJH, JC MIEOG, Sinclair WA. Community change in the algal endosymbionts of a scleractinian coral following a natural bleaching event: field evidence of acclimatization. Proc Royal Soc Lond B Biol Sci. 2008;275(1641):1359-65. https://doi.org/10.1098/rspb.2008. 0069.

134. Little AF, Van Oppen M, Willis BL. Flexibility in algal endosymbioses shapes growth in reef corals. Science. 2004;304(5676): 1492-4. https://doi.org/10.1126/science.1095733.

135. Coffroth MA, Poland DM, Petrou EL, Brazeau DA, Holmberg JC. Environmental symbiont acquisition may not be the solution to warming seas for reef-building corals. PLoS One. 2010;5(10): e13258. https://doi.org/10.1371/journal.pone.0013258.

136. LaJeunesse TC, Smith RT, Finney J, Oxenford H. Outbreak and persistence of opportunistic symbiotic dinoflagellates during the 2005 Caribbean mass coral "bleaching" event. Proc Royal Soc Lond B Biol Sci. 2009;276(1676):4139-48. https://doi.org/10. 1098/rspb.2009.1405.

137. LaJeunesse TC, Loh W. Low symbiont diversity in southern great barrier reef corals, relative to those of the Caribbean. Limnol Oceanogr. 2003;48(5):2046-54. https://doi.org/10.4319/lo.2003. 48.5.2046.

138. Chakravarti LJ, Beltran VH, van Oppen MJH. Rapid thermal adaptation in photosymbionts of reef-building corals. Glob Chang Biol. 2017;275:2273. 
139. Rohwer F, Seguritan V, Azam F, Knowlton N. Diversity and distribution of coral-associated bacteria. Mar Ecol Prog Ser. 2002;243:1-10. https://doi.org/10.3354/meps243001.

140. Bayer T, Neave MJ, Alsheikh-Hussain A, Aranda M, Yum LK, Mincer T, et al. The microbiome of the Red Sea coral Stylophora pistillata is dominated by tissue-associated Endozoicomonas bacteria. Appl Environ Microbiol. 2013;79(15):4759-62. https://doi. org/10.1128/AEM.00695-13.

141. Morrow KM, Moss AG, Chadwick NE, Liles MR. Bacterial Associates of two Caribbean Coral Species Reveal SpeciesSpecific Distribution and Geographic Variability. Appl Environ Microbiol. 2012;78(18):6438-49. https://doi.org/10.1128/AEM. 01162-12.

142. Bourne DG, Morrow KM, Webster NS. Insights into the coral microbiome: underpinning the health and resilience of reef ecosystems. Annu Rev Microbiol. 2016;70(1):317-40. https://doi. org/10.1146/annurev-micro-102215-095440.

143. Santos HF, Carmo FL, Duarte G, Dini-Andreote F, Castro CB, Rosado AS, et al. Climate change affects key nitrogen-fixing bacterial populations on coral reefs. ISME J. 2014;8(11):2272-9. https://doi.org/10.1038/ismej.2014.70.

144. Reshef L, Koren O, Loya Y, Zilber-Rosenberg I, Rosenberg E. The coral probiotic hypothesis. Environ Microbiol. 2006;8(12): 2068-73. https://doi.org/10.1111/j.1462-2920.2006.01148.x.

145. Peixoto RS, Rosado PM, Leite DC. De a, Rosado AS, Bourne DG. Beneficial microorganisms for corals (BMC): proposed mechanisms for coral health and resilience. Front Microbiol. 2017;8:100.

146. Webster NS, Reusch TB. Microbial contributions to the persistence of coral reefs. ISME J 2017;11:2167-74. https://doi.org/10. 1038/ismej.2017.66.

147. Madin JS, Hoogenboom MO, Connolly SR, Darling ES, Falster DS, Huang D, et al. A trait-based approach to advance coral reef science. Trends Ecol Evol. 2016;31(6):419-28. https://doi.org/10. 1016/j.tree.2016.02.012.

148. Mumby PJ. Embracing a world of subtlety and nuance on coral reefs. Coral Reefs 2017;1-9.

149. Reusch TBH. Climate change in the oceans: evolutionary versus phenotypically plastic responses of marine animals and plants. Evol Appl. 2013;7:104-22.
150. Császár NBM, Ralph PJ, Frankham R, Berkelmans R, van Oppen $\mathrm{MJH}$. Estimating the potential for adaptation of corals to climate warming. PLoS One. 2010;5(3):e9751. https://doi.org/10.1371/ journal.pone.0009751.

151. van Oppen MJH, Oliver JK, Putnam HM, Gates RD. Building coral reef resilience through assisted evolution. Proc Natl Acad Sci U S A. 2015;112(8):2307-13. https://doi.org/10.1073/pnas. 1422301112.

152. Macharia D, Grimsditch G, Abdulla A, Obura D. Mapping factors that contribute to coral reef resilience using in situ and satellite data in East Africa. In: Diop S, Scheren P, Ferdinand Machiwa J, editors. Estuaries: a lifeline of ecosystem services in the western Indian Ocean. Cham: Springer International Publishing; 2016. pp. 259-76.

153. Morgan KM, Perry CT, Smithers SG, Johnson JA, Daniell JJ. Evidence of extensive reef development and high coral cover in nearshore environments: implications for understanding coral adaptation in turbid settings. Sci Rep 2016;6:29616. https://doi.org/ 10.1038/srep29616.

154. Abelson A, Nelson PA, Edgar GJ, Shashar N, Reed DC, Belmaker $\mathrm{J}$, et al. Expanding marine protected areas to include degraded coral reefs. Conserv Biol. 2016;30(6):1182-91. https://doi.org/ 10.1111/cobi.12722.

155. Mellin C, MacNeil Aaron M, Cheal AJ, Emslie MJ, Julian Caley M. Marine protected areas increase resilience among coral reef communities. Ecol Lett. 2016;19(6):629-37. https://doi.org/10. 1111/ele.12598.

156. Mumby PJ, Harborne AR. Marine reserves enhance the recovery of corals. PLoS One. 2010;5(1):e8657. https://doi.org/10.1371/ journal.pone.0008657.

157. Graham NA, Bellwood DR, Cinner JE, Hughes TP, Norström AV, Nystrom M. Managing resilience to reverse phase shifts in coral reefs. Front Ecol Environ. 2013;11(10):541-8. https://doi.org/10. 1890/120305.

158. Hughes TP, Barnes ML, Bellwood DR, Cinner JE, Cumming GS, Jackson JBC, et al. Coral reefs in the Anthropocene. Nature. 2017;546(7656):82-90. https://doi.org/10.1038/nature22901.

159. Norström AV, Nystrom M, Jouffray JB. Guiding coral reef futures in the Anthropocene. Front Ecol Environ. 2016;14(9):490-8. https://doi.org/10.1002/fee.1427. 